Review Article

\title{
Culture and Symbolism Nexus in Anthropology
}

\author{
Surya Bhakta Sigdel \\ Adjunct Faculty, Janapriya Multiple Campus \\ Email: sigdelsb@gmail.com
}

Article History

Received 26 April, $2018 \quad$ Revised 9 July $2018 \quad$ Accepted 30 November 2018

\begin{abstract}
Study of symbols or the theory of symbolism makes micro study of the culture. Symbols are the gestures, objects and language, which form the basis of human communication. Interpretation of symbol may differ according to the culture. At the same time a symbol may have one meaning in one culture another meaning in another culture. Symbols represent signs which are used to signify objects, real or imaginary. Symbols are arbitrary based on convention of culture. Interpretation of symbol depends on culture. Symbols are means of Communication of language, a form of ritual expression, cultural interpretation, expression of art and belief. Symbols should not be looked at in an abstract way and at meaning as constructed apart from human action but rather at the way meaning is constructed and used in the context of this action. Symbolism studies how a culture functions on the basis of its meanings, how a symbol is interpreted and so on. Symbolism studies the interrelationship between culture, language and people. Culture is constructed on the basis of different symbols. There are different meanings of symbols. The same symbol in different contexts may have different kinds of meanings. Symbols are directed by cultural norms. As cultural norms are diverse symbols too are multicoil, multifocal and multivariate and they can represent many things. Symbols do not necessarily have the same meaning in different context. Thick description by Clifford Geertz takes into account the fact that any aspect of human behavior has more than one meaning.
\end{abstract}

Keywords: Communication, paradigm, symbolic anthropology, thick description

(C) The Author. Published by JRCC, Janapriya Multiple Campus

ISSN 2362-1516

\section{Introduction}

As a theory for the micro study of culture the theory of culture and symbolism also called Symbolic Anthropology became perceptible after World War II. This theory shows the importance of symbols in a culture. Symbols are the gestures, which form the basis of human communication. Although, there remains an important role of symbols in a culture, interpretation of symbol may differ according to the culture. At the same time a symbol may have one meaning in one culture another meaning in another culture. The 
meaning of symbols depends on individual definition of gestures. Symbols are the gestures, objects and language, which form the basis of human communication.

Symbols exist in diverse forms:

Symbols as means of Communication of language, Symbols as a form of Ritual Expression Symbol as a form of Cultural Interpretation, Symbol as a form of the Expression of Art and belief, Symbol as a form of Psychological Expression, Symbols as a form of analysis of attributes.

Language and symbols are interrelated and there exists an important role of cultural patterns, which include systems of beliefs or ideas, systems of expressive symbols and systems of value orientations. In this regard, Clifford Geertz says that culture is a historically transmitted pattern of meanings embodied in symbols, a system of inherited conceptions expressed in symbolic forms by means of which mean communicate, perpetuate and develop their knowledge about the attitude towards life. For him symbol is any object, event, quality or relation, which serves as a vehicle for conception; the conception is the meaning of the symbol and meaning is embodied in symbols.

It was during sixties that anthropologists in the United States and Europe reacted against the utilitarian conceptions of human behavior in society. Instead of explaining behavior like the functionalist approach had advocated they raised questions about the meaning of behavior to the actors of the culture. Due to this in the sixties and seventies a new or another kind of Anthropology began to appear and it was Symbolic Anthropology. This newly emerged symbolic Anthropology never had a clear center, but a number of people had a concern for interpreting the symbolic structures symbols or complexes as a way of trying to understand the basis of culture since they went about it in different ways.

Symbolic anthropologists Clifford Geertz, Mary Douglas, David Schneider treated culture as more open-ended. They treated culture with in the perspective of concrete reality and started to look at culture in the way symbols give meaning to and gain meaning form specific context of social action: like gossiping, rituals, cock fights and all kinds of everyday activities. Symbolic anthropologists believe that symbols should not be looked at in an abstract way and at meaning as constructed apart form human action but rather at the way meaning is constructed and used in the context of this action.

\section{Conjectures of Symbolism and Culture Nexus}

Symbolic theory is concerned primarily with the subjective meaning that individuals give to their and other's action. Anthropologists Mary Douglas has argued that symbol is the main instrument of thought and the only regulator of experiences. Leslie White even says that a symbol may have any kind of physical form, material object, sound, taste, color or our, notion of an object. Thus, the value and meaning of a symbol is in no instancederived form the properties intrinsic in its physical form. Meaning is bestowed by human 
organisms upon physical things or events, which there upon become symbol with a meaning.

Clifford Geertz rejected the cognitive view of culture because he said "it" locates meaning inside people's heads. The focus of Clifford Geertz's concern is the public social aspects of meaning. Symbolic anthropologist David Schneider says that when a symbol refers to an entity, the entity can never be said to be the signification or the meaning of the symbol. Symbolist converse on how symbols operate in actions and the interactions of individuals.

The basic assumptions of culture and symbolism are as follows:

a) In all societies different types of symbols exits which gives different meanings.

b) Symbol controls and guides man, social activities, behavior etc.

c) Culture fulfills human needs and language is a medium of expression. Likewise symbolism studies the interrelationship between culture, language and people.

d) Social and cultural system is mobilized by symbols and the culture is a network of symbols

e) Culture is constructed on the basis of different symbols e.g. Cockfights of Balinese people where victorious is regarded as a hero for a certain period. And all these support the norms and values of a society /culture.

f) There are different meaning $s$ of symbols. The same symbol in different contexts may have different kinds of meanings. The focus of the ethnographer must be on the symbols.

g) Although the focus of the ethnographer must be on symbols, the analysis must not be divorced from the informal logic of everyday life or actual life on which it operates. One must pay attention both to the symbols the way in which the symbols are constituted to the context in which they are used. Cultural analysis of this type therefore is interpretive in character and that is why people call this interpretive Anthropology -the goal is to interest or unravel the meanings of symbols and symbols system as a way of trying to understand cultural process.

h) Symbols are directed by cultural norms. As cultural norms are diverse symbols too are multicoil, multifocal and multivariate and they can represent many things. Symbols do not necessarily have the same meaning in different context. In one context green may be male in another female.

\section{Variants of Culture and Symbolis m}

Various scholars contributed in the field of symbolic Anthropology, which became a branch of American Anthropology viz. John Dewey, W. James, C.H Cooley, J.H Mead, W.J Thomas, V. Turner, H. Blumer, E. Goffman, etc. These early symbolists's work helped the new scholars whose contributions are regarded prominent. Among these new scholars C. Geertz, V Turner, Schneider, M. Douglas are prominent contributors. The basic question that is being posed by symbolic anthropologists is how are symbols and systems of symbols used by human beings to provide order to their social lives? 


\section{Clifford Geertz and Thick Description}

The main concern of American anthropologist Clifford Geertz's is that he wants all to understand a culture in its own terms. According to him culture is a historically transmitted pattern of meanings embodied in symbols, a system of inherited conceptions expressed on symbolic forms by means of which men communicate, perpetuate and develop their knowledge about the attitude towards life. For him symbol is any object, event, quality or relation, which serves, as a vehicle for conception, the conception, is the symbols meaning.

Clifford Geertz says that culture is a set of control mechanism for governing people's behavior. The mechanism operates on public via significant symbols. For him culture constitutes the webs of significance, symbol and to expose these meaning is the challenge of anthropologists. While writing about culture and symbols, Geertz is in a search for meanings, for application.....indeed, literary explanation ......and not for laws of experimental science. Interpretation is the tool he uses to achieve this goal of excavating for meaning. Geertz developed the concept of thick description which takes into account the fact that any aspect of human behavior has more then "one meaning.

Geertz in order to clarity the role of symbols in a culture, studied the Balinese culture of the Bali island of Indonesia and wrote about their "cock-fight" The cock fight culture among the people of Bali with its symbolic significance was presented by Geertz in his work Notes on the Balinese cockfight. He has written that, April of 1958, he along with wife arrived; malarial and diffident (shy), in a Balinese village they intended as anthropologists to study. In Bali he noticed cockfight. Although, by the time, a few special occasions aside cockfight was illegal in Bali under the Republican government of Military Dictator General Suharto. As a result, the fights were usually held in a secluded corner of a village in semi secrecy, a fact which tends to slow the action little not very much, but the Balinese do not care to have it slowed at all Geertz has written that the third match was interfered by policemen (as cockfight was illegal). After the police retreated, the cockfight took place another day.

Cockfights (Called Tetadjen Sabungan in Balinese language) used to be held in a ring about 50 feet square. Usually they begin toward late afternoon and run three or four hours until sunset. Each match was precisely like the others in general pattern; there was no main match, no connection between individual matches, no variation in their format, and each arranged on a completely ad hoc basis. After a fight has ended and the emotional debris is cleaned away the bets have been paid, the curses cursed, the carcasses possessed seven, eight, perhaps even a dozen went slip negligently into the ring with a cock and seek to find there a logical opponent for it. Narrating all these incidents Geertz further 
says that the cockfight in Bali looks as if people are betting over fights and that a lot of communication is taking place. Then he shows as he peels off different layers how the cockfight is a reenactment or rebuilding of Balinese society and all of the major principles of status and rules of interaction are essentially dramatized and acted out in the context of the cockfight. The Balinese used to portray themselves and their culture through the symbols.

After the study of Balinese cockfight Geertz traced out the following points:

I. For the Balinese people, there is metaphorical significance of cockfight. Although cockfight was banned, cock for them the symbol of champion, hero, warrior or even ladykiller or a bachelor etc.

II. For the Balinese people, cockfight is the symbol of masculine per excellence. In Bali culture, cockfight is the fight of courageous, brave and strong males and being the game of males no woman or hen can participate in the fight.

III. Balinese people used to take cockfight as a gamble where they make speculations and bet that their cock will be victorious. A victorious cock brings prestige prosperity to its owner and he is considered rich person in the community. But if his cock is defeated he is not regarded as prosperous. It is thought that as he is not rich enough to take nutritious food, his cock too is malnourished and not strong enough to be victorious.

IV. For the Balinese people cockfight is the game of superior and senior male citizens where they make bet of money. There are two sorts of bets, or toh (Balinese language which means stain or mark). There is the single axial bet in the center between the principals (Toh Ketengah in Balinese language) and there is the cloud of peripheral ones around the ring between members of the audience. It is a game related with power and to some extent even politics where poor and weak are debarred from participation.

\section{Victor Turner and the Characteristics of Symbols}

Victor W. Turner is a Scotsmen born in 1920 in Glasgow and died in 1983. As a symbolist Turner was interested in the characteristics of symbols and the ways they condense meaning or capture meaning. Turner says that the same symbol can be used to designate good or bad so what they mean is that you can't take a symbol and say it stands for something and only one thing. Symbols, says Turner, by their nature are multifocal and multivariate and they can represent many things at the same time. In one context "Red" may be male and in another female. Symbols are dynamic entities and static cognitive signs. They are patterned by events and enforced by the positions of human inter connection in friendship, sexuality and politics.

Victor Turner conducted his study among the Ndembu tribe of Zambia (Africa). In his study of Ndembu society, Turner explored that Ndembu culture had helped to maintain the status of the tribe. The Ndembu people used to worship their ancestors after and before hunting the animals. They use five types of trees for worshipping on the basis of giving priority to the first tree they come across. The name of one tree was Chisinga 
meaning curse. The second tree was Musoli meaning 'to increase or enhance'. The Ndembu people used to take the branch of any one of the tree and cut it into $\mathbf{V}$ shape with branches. They used to put the horn of hunted animals at the top and animal flesh in the branches and used to wash the ground with animal blood. It is widely believed among Ndembu that the blood act as a protection against flies and mosquitoes. Symbolically the flesh put in the branches was regarded as leaves and fruits. The pointed branch means tender leaves and the blood used for washing the ground means water. Removing the bark of tree branches symbolically denoted the clean heart of Ndembu people. Pointed branches and keeping flesh meant that the Ndembu people are expert hunters and they never miss their prey (animal).

For Ndembu Chisinga tree is curse. This tree also denotes pace (speed) and women. Musoli was regarded a boon because this tree bear sweet fruits and when wind blew deer's used to come to eat the fruits and Ndembu used to kill these deer's. Musoli was helpful for killing deer's and hunting animals bring high status among Ndembu tribe thus Musoli was regarded a good tree or a boon. Musengu tree bear extra sweet fruits and was symbolically regarded more beneficial as more deer's used to come to this tree to eat sweet fruits.

\section{Pollution and Purity of Mary Douglas}

As a symbolic anthropologist Mary Douglas sees ideas and symbols as systems of thought. Some of the symbolic anthropologists like Geertz tend to emphasize the emotional effects whereas like David Schneider and Mary Douglas emphasize the cognitive aspects. Douglas is more concerned with the meaning of symbols and how people use them to construct a worldview.

While writing about the meaning of symbols in her book Purity and Danger (1966) Douglas has mentioned in tribute that she was first interested in pollution behavior by professor M.N. Srinivas and Franz Steiner who each, as Brahmin and Jew, tried in their daily lives to handle problems of ritual cleanness. Douglas says no particular set of classifying symbols can be understood in isolation, but there can be hope of making sense of them in relation to total structure of classifications in culture in question.

For Mary Douglas's symbol are the main instrument of thought and the only regulator of experience. Symbol for her is structure communication, a whole system of order. She note symbols in relationship to the whole system of orders - conceptual structure. For Douglas "Holism" emphasizes both orders, she tried to clear "Holism" in reference to boundary purity, ritual purity, population etc. According to Douglas in all societies there are certain rules and regulation and if someone tries to cross that boundary, he/she becomes impure. An idea such as the idea of pollution has been one of her main interest. 
This has meaning not in isolation but also in reference to the total structure of thought whose boundaries are maintained by cultural practice. She is concerned mainly with ideas - like how the ideas of pollution operate in a system of action. The purpose of the system is order and this is a central point: order is central to people's views of the world. Culture then is a way of providing order to our experience and that people have a strong need for a sense of order and when it is violated we respond with strong feeling.

Douglas believed that the system of ideas and symbolism are units that depend upon each other for meaning. Pollution, for example, only exists as an idea in relation to the idea of purity. She suggests that the concepts of order are associated with such ideas as holiness, wholeness, and morality. Purity is associated with wholeness and morality and disorder is associated with pollution incompleteness, and immorality. Dirt can be conceptualized as matter out of place. Or, what people see as polluting or dirty is basically matter out of place implying that it violates a system of ordered relationships.

As a symbolic anthropologist, Douglas argues that we have a sense of order and those things that violate our sense of order and are out of category are responded to do with anxiety, disgust, etc. For example if we are chewing a cough drop we are flavoring out spit and swallowing it. If we spit our saliva into a glass and drink it then it would be disgusting. If we spit our saliva into a glass and drink it, it would be disgusting, but the material there is the same. So once saliva leaves the body we regard it as matter out of place. Pollution rules support clarification of forms and they reduce our sense of dissonance. Pollution beliefs reinforce the culture and social structure and reduce ambiguity in the moral sphere. They not only enhance our order, but also protect those areas of culture most vulnerable to disruptive aspects of the ambiguity. For example in many cultures common pollution beliefs is that menstrual blood is polluting. Due to which women are debarred (prohibited or kept away) from various kinds of activities social and religious, activities. In the Nepalese context also menstrual women are debarred from attending religious and other rituals. Douglas argues that menstrual blood is matter out of place. But the interesting point to be noted is that sacrificial blood is regarded holy and not polluting since it is shed within the control of the conceptual system.

Douglas presented the idea that Jewish and Islamic avoidance of pig-meat (pork) is due to dangers of eating pig in hot climates. She says that there can be marvelous correspondence between the avoidance of contagious disease and ritual avoidance of contagious disease and ritual avoidance. The washings and separations which serve the one practical purpose may be apt to express religious themes at the same time. So it has been argued that their rule of washing before eating may have given the Jews community in plagues. But one thing to point out is the side benefits of ritual actions, and another thing to be content with using the by-products as a sufficient explanation. 
She said that Israeli people believe that their army should be united and should follow rituals properly. For it solders need to be pure. It is believed that Israeli army wins because of their purity. While taking about the concept of purity she has illustrated a hoary old puzzle from biblical scholarship, the "Abomination of Leviticus", and particularly the dietary rules. Why should the camel, the hare and the rock badger be unclean? Why should some locusts, but not all, be unclean and why should the frog be clean and the mouse and hippopotamus unclean? What have chameleons, moles and crocodiles got in common that they should be listed together?

In her book Purity and Danger she talked about "Magic and Miracle" and referred example of Kung Bushmen who performed their rain rituals to bring rain. The Dinka tribe of Africa too performs all annual ceremony to cure malaria. The ceremony is timed for the month in which it is to be expected that malaria will soon abate. We can cite examples from Soraha of Nepal Terai where people arrange the marriage of frogs in the anticipation of rain.

\section{Conclusion}

Culture and symbolism is a reaction against the utilitarian conceptions of human behavior in the society, with the passage of time symbolic anthropology was criticized for its loopholes viz it rejects the existence of social structure, concentrates only on symbols and meaning, ignores history, economy politics. Culture and symbolism has never had a clear center, but a number of people had a concern for interpreting the symbolic structures, or complexes as a way of trying to understand the basis of culture. Also, symbolic anthropology has no regard for human needs, social change, motivation, desire etc but it gives priority only to the definition of symbols. Symbols are abstract thus making difficult the interpretation. It is hard to pin down a symbolic anthropology paradigm like that of structuralism, functionalism etc. Despite criticism, symbolic anthropology has been able to establish itself as a strong and reliable theory, competent enough to cope with the meanings and symbols rampant in different cultures of the world.

\section{References}

Clifford, J. (1986). The Predicament of Culture. Harvard University Press.

Conklin, H. (1963). The Study of Shifting Cultivation. Washington: Technical Publications.

Douglas, M. (1966). Purity and Danger. California: Harcourt and Bavourd. 
Ananta Raj Dhungana Janapriya Journal of Interdisciplinary Research, Vol. VII, 2018

Frake, C. (1961). The diagnosis of diseases among the Subanum of Mindanao. Washington: American anthropology.

Geertz, Clifford (1973). The Interpretation of Culture. New York: Basic book Inc.

Harris, M. (1968). The Rise of Anthropological Theories. California: The Crowell publication.

Mead, M. (1928). Coming of age in Samoa. New York, Morrow.

Turner, H. J. (1995). The Structure of Sociological Theory. Jaipur, Rawat Publication.

Wallace, W. L (1971). (Eds.). Sociological Theory, London, H.E.B. publishers. 